\title{
Impact of Land Use/Cover Change on Hydrologic Characteristics: A Study on Upper Narmada Basin (MP), India
}

\author{
Subhash Thakur $^{1 *}$, M.K. Hardaha ${ }^{1}$ and Prashant Srivastava ${ }^{2}$ \\ ${ }^{1}$ Department of Soil and Water Engineering, India \\ ${ }^{2}$ KVK Narsinghpur JNKVV (M.P.), India \\ *Corresponding author
}

\section{A B S T R A C T}

Keywords

Land use /Land

Cover (LULC),

RS/GIS and SWAT

model

Article Info

Accepted:

10 January 2018

Available Online:

10 February 2018
This paper presents an integration approach involving Remote sensing / Geographic information system(RS /GIS) and hydrological models to characterized and quantify the effect of land use/ land cover (LULC) change on basin hydrology parameters. The Arc SWAT model was used daily weather and stream flow data of Upper Narmada basin from 1989 to 2011. Study evaluates change in Surface runoff, Evapo-transpiration, Total water yield, stream flow and Total aquifer recharge. Further analysis present additional evidence that changes in vegetation cover altered the hydrological response to region. As the pressure for changes in LULC in the region continuous to increase, one can expect important further change in the hydrological regime of the basin.

\section{Introduction}

Precipitation and land hydrological processes maintain the water balance in a river basin. Land surface performs a role in the hydrological cycle, as water availability is generally a consequence of precipitation redistributed into evaporation, runoff and soil moisture storage (Dolman and Verhagen 2003). The largest part of precipitation passes over the land surface or drain through the soil and bedrock to translate into river flows. The spatial heterogeneity associated with land cover, soil properties and localized precipitation influences soil moisture and surface fluxes. Land cover change and the effects of land management on the hydrological response of a catchment are most likely where the change alters the surface characteristics of a basin. The degree and type of land cover influences surface run-off and the rate of infiltration, and consequently the rate of groundwater recharge (Calder, 2002; Dingman, 2008). Changes in these hydrological variables may have implications for water resources.

The relationship between land cover change and hydrology is complex, with linkages existing at a wide variety of spatial and 
temporal scales. However, land cover change unquestionably has a strong influence on global water yield (Frenierre2009). Land cover and use directly influence the amount of evaporation, groundwater infiltration and overland runoff that occurs during and after precipitation events (Zhang et al., 2001, Costa 2003). Forests have a higher interceptive potential than grassland, arable land lower than grassland. Conversion to cropland tends to increase water yield compared to native vegetation although this varies with the crop and the season while manmade surfaces such as tarmac have the lowest interceptive potential (Haslam, 1987).

Comprehensive knowledge of Land use /Land Cover (LULC) dynamics is useful for reconstructing past land use and cover changes and for predicting future changes. It may help in elaborating sustainable management practices aimed at preserving essential landscape functions (Hietel et al., 2004). Though many land use models have been developed using GIS (Almeida et al., 2008, Xia and Xiaoping, 2008), a simple approach was taken for scenario analysis of this study due to limited data access.

\section{Materials and Methods}

\section{The study area}

The Upper Narmada basin is located across the central part of Madhya Pradesh and it is distributed in Dindori, Jabalpur, Mandla, Narsinghpur, Hoshangabadare considered for the study. Total area of the basin is about $45,286 \mathrm{~km}^{2}$. The basin is surrounded by latitude $22^{\circ} 40^{\prime} \mathrm{N}$ and longitude of $81^{\circ} 45^{\prime} \mathrm{E}$ shown in Figure 1 . The climate of the basin is humid and tropical, although at places extremes of heat and cold are often encountered. The average annual (1989-2011) rainfall in the upper Narmada basin varies from $1400 \mathrm{~mm}$ at eastern region to $1650 \mathrm{~mm}$ to western region.

\section{Data collection and analysis}

In the study data required for assessing impacts of Land use/ land cover (LULC) change on hydrology over the Upper Narmada basin, were obtained digital elevation model (DEM) and Satellite Images (Resourcesat-1 LISS-III duration October-November 2011) from bhuvan.nrsc.gov.in, MSS and Landsat TM duration October-November 1989) Landst.org, these data were processed in ERDAS IMAGINE 2010 performed unsupervised classification for LULC map preparation, soil maps at scale 1:25,00,000 from National Bureau of Soil Science and Land Use Planning (NBSS and LUP, 1996) for Madhya Pradesh. Meteorological data consist of daily precipitation, maximum and minimum temperature, relative humidity, wind speed, and solar radiation were obtained from globalweather.tamu.edu. Observed discharge data was used for model calibration were obtained by indiawris.nrsc.gov.in.

\section{Hydrological Model}

In this study ArcGIS interface of SWAT model version 2009 was used, which is physically-based, semi distributed and continuous time step model and used for predicting the impact of different LULC effect on hydrology (Neitsch et al., 2011). Arc SWAT simulate hydrologic cycle based on water balance. The general eq. is:

$$
S W_{t}=S W_{0}+\sum_{i=1}^{t}\left(R_{\text {day }}-Q_{\text {surf }}-E_{a}-W_{\text {seep }}-Q_{g w}\right)
$$

Where, $\mathrm{SW}_{\mathrm{t}}=$ final soil water content $(\mathrm{mm})$, $\mathrm{SW}_{\mathrm{o}}=$ initial soil water content $(\mathrm{mm}), \mathrm{t}=$ simulation period (days), $\mathrm{R}_{\text {day }}=$ amount of precipitation on the $\mathrm{i}^{\text {th }}$ day $(\mathrm{mm}), \mathrm{Q}_{\text {surf }}=$ amount of surface streamflow on the $i^{\text {th }}$ day $(\mathrm{mm}), \mathrm{E}_{\mathrm{a}}=$ amount of evapotranspiration on the $\mathrm{i}^{\text {th }}$ day $(\mathrm{mm}), \mathrm{W}_{\text {seep }}=$ amount of water 
entering the vadose zone from the soil profile on the $\mathrm{i}^{\text {th }}$ day $(\mathrm{mm})$, and $\mathrm{Q}_{\mathrm{gw}}=$ amount of base flow on the $\mathrm{i}^{\text {th }}$ day $(\mathrm{mm})$.

With the help of Arc SWAT model LULC, SLOPE, and SOIL map were used to simulate and create sub-basin and hru for the study. The model uses SCS model (Wieshmeir and smith 1978) to estimate the surface runoff.

\section{Results and Discussion}

The SWAT model simulated for the two time periods corresponding to the LULC of 1989 and 2011. A comparison of the selected parameters for LULC 1989 and 2011 effect of changing scenario of LULC for mean annual surface runoff, Aquifer recharge, water yield and Evapotranspiration presented in (Table 1 and Figure 2).

The result indicate that changes in LULC from 1989 to 2011 annual surface runoff and total aquifer recharge was decreased $1.62 \%$ and $8.13 \%$ respectively. Also analyzed that total water yield was decreased by $6.90 \%$ but evapo-transpiration increases by $2.21 \%$ from 1989 to 2011 LULC.

Table.1 Parameters from annual simulations for 1989 and 2011 LULC

\begin{tabular}{|l|}
\hline Item (unit $=\mathbf{m m}$ ) \\
\hline Surface Runoff \\
\hline Total Aquifer Recharge \\
\hline Total Water Yield \\
\hline Evapotranspiration \\
\hline
\end{tabular}

\section{LULC_1989 $\quad$ LULC_2011}

Fig.1 Map of the study area

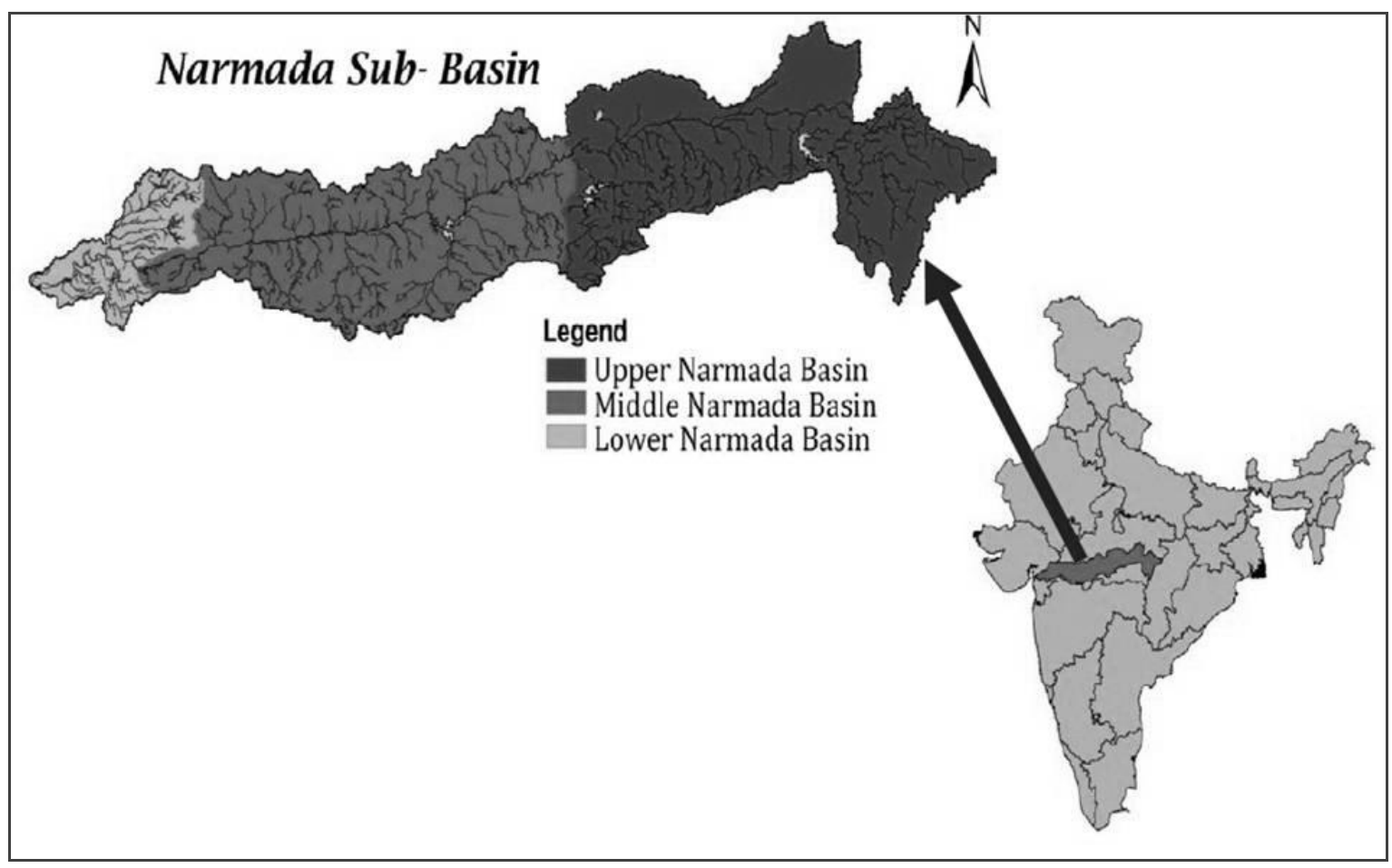


Fig.2 Hydrologic response to land use/land cover change for 1989 and 2011

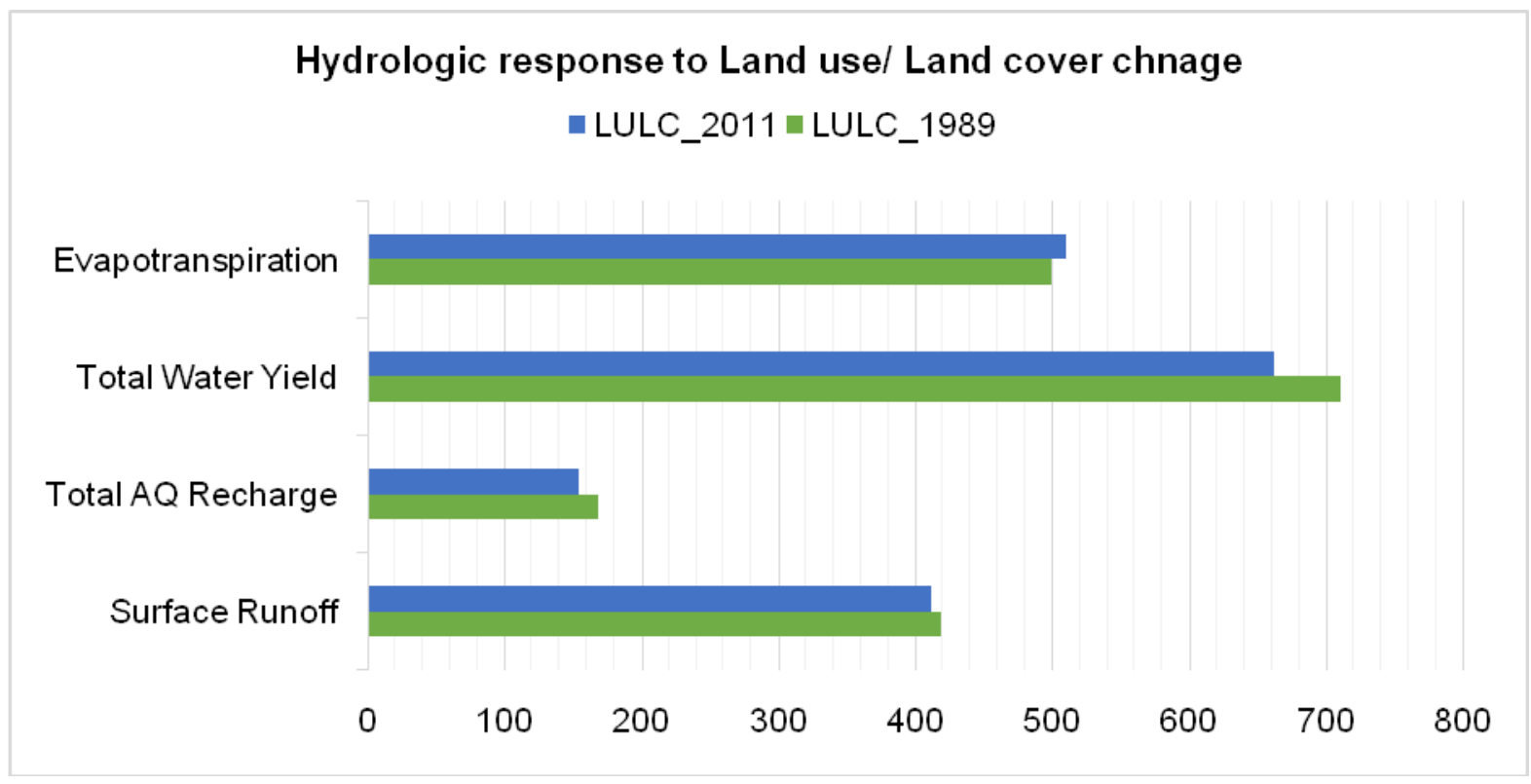

It can be presumed that the rapid increase in human population has altered the basin. Modifications of land uses are expected in the near future, since farmers in the Upper Narmada basin have already started using ground water and surface water to cultivate market oriented crops. This study also highlighted that detail understanding of historical land use/cover changes and consequent impacts on hydrology will enhance our capability to predict future land use modifications. Therefore, further scenario simulations and optimization strategies that take in to account upstream-downstream water users can provide valuable information to devise more effective management strategies to sustain the livelihoods of the local community.

\section{Acknowledgement}

The author sincerely acknowledge the data provider national and international agencies like indiawris.nrsc.gov.in, globalweather. tamu.edu., bhuvan.nrsc.gov, also acknowledge the RS and GIS Lab of Department of Soil and Water Engineering,
College of Agricultural Engineering, JNKVV University-482004, providing complete lab facility for study and research work.

\section{References}

Almeida CM, Gleriani JM, Castejon EF, Soares-Filho BS 2008. Using neural networks and cellular automata for modelling intra-urban land-use dynamics. International Journal of Geographical Information Science, 22(9): 943-963.

Bhuvan.nrsc.gov.in

Calder IR 2002. Forests and hydrological services: Reconciling science and public perceptions. Land Use and Water Resources research, 2, 2.1-2.12

Costa MH, Botta A, Cardille JA 2003. Effects of largescale changes in land cover on the discharge of the Tocantins River, Southeastern Amazonia. Journal of Hydrology, 283(1-4): 206-217.

Dingman SL 2008. Physical Hydrology. 2nd Edition (reissued), Long Grove., Illinois: Waveland Press. 
Dolman AJ, Verhagen A (Eds.) 2003. Land Use and Global Environment Change, in Global Environmental Change and Land Use. Dordrecht, Netherlands: Kluwer Academic.

Frenierre JL 2009. The relationship between Land Cover Change and Water Resources Vulnerability: A review of Existing Literature. From http://www. lafrenierre.net/ uploads.pdf (Retrieved on 23 May 2011).

Globalweather.tmu.edu

Haslam SM 1987. River plants of Western Europe: The Macrophytic Vegetation of Water Sources of the European Economic Community. Cambridge: Cambridge University Press

Hietel E, Waldhardt R, Otte A 2004. Analyzing land-cover changes in relation to environmental variables in Hesse, Germany. LaCosta MH, Botta A, Cardille JA 2003. Effects of largescale changes in land cover on the discharge of the Tocantins River, South eastern Amazonia. Journal of Hydrology, 283(1-4): 206-217.ndscape Ecology, 19: 473-489.
Indiawris.nrsc.gov.in

Landsat.org

Neitsch, S L, J G Arnold, J R Kiniry and J R Williams 2011. Soil and Water Assessment Tool Theoretical Documentation Version 2009 (Texas A and M University, Texas).

Soils of Madhya Pradesh for optimizing Land Use, NBSS Pub.59 b, 1996, ISBN: 8185460-32-9.

Wischmier W H and D.D.Smith.1978. Predicating rainfall losses: A Guide to conservation planning. USDA Agricultural Handbook No. 537. U.S. Gov. Print. Office, Washington, D.C.

Xia L, Xiaoping L 2008. Embedding sustainable development strategies in agent-based models for use as a planning tool. International Journal of Geographical Information Science, 22: 21-45.

Zhang L, Dawes W.R, Walker GR 2001. Response of mean annual evapotranspiration to vegetation changes at catchment scale. Water Resources Research, 37: 701-708.

\section{How to cite this article:}

Subhash Thakur, M.K. Hardaha and Prashant Srivastava. 2018. Impact of Land Use / Cover Change on Hydrologic Characteristics: A Study on Upper Narmada Basin (MP), India. Int.J.Curr.Microbiol.App.Sci. 7(02): 1206-1210. doi: https://doi.org/10.20546/ijcmas.2018.702.148 